To Cite This Article: Çabuk, S. N. (2019). Introduction of Turkish vocational qualifications for geographical information systems related jobs. International Journal of Geography and Geography Education (IGGE), 40,393-405.

\title{
INTRODUCTION OF TURKISH VOCATIONAL QUALIFICATIONS FOR GEOGRAPHICAL INFORMATION SYSTEMS RELATED JOBS
}

Saye Nihan ÇABUK ${ }^{1}$

\begin{abstract}
Geographical Information Systems (GIS) certification has become one of the assets enabling the recognition of the knowledge, skills and competencies of the persons working in a wide range of jobs and projects. Regarding this fact, the General Directorate of GIS, Turkish Ministry of Environment and Urbanization, was involved in the process of national vocational standards and qualifications development for GIS related jobs between 2013-2016. Accordingly, the main aim of this paper is to explain the process and give information about the results of the research projects and collaborative works realized in order to develop national vocational standards, vocational qualifications and a certification system for GIS Operator (Level 4) and GIS Specialist (Level 6). The overall process was mostly realized in collaboration with the Earth and Space Sciences Institute of Eskisehir Technical University (former Anadolu University), as well as other participants from various institutions, and continued along with two supplementary research projects that were aimed at the development of a comprehensive certification system for the Ministry of Environment and Urbanization. The research projects comprised the stages of detailed analysis and evaluations about the administrative, legal and technical requirements in accordance with the national vocational qualifications system and ISO/IEC 17024 standard, and were followed with the development of an integrated software to manage all the stages of the vocational certification, online examination, question bank development and quality assurance system. The results are believed to be valuable and triggering inputs for the development of other necessary vocational standards and qualifications for GIS related jobs, raise awareness for the necessity of vocational certification and help improve the context and quality of the GIS training/education curricula in the country.
\end{abstract}

Keywords: GIS Certification, GIS Jobs, GIS Standards, National Qualification

\footnotetext{
${ }^{1}$ Assoc. Prof., Eskişehir Technical University, Earth and Space Sciences Institute, Department of Geodesy and Geographical Information Technologies, iki Eylül Campus, 26555, Eskişehir, TURKEY., https://orcid.org/0000-0003-4859-2271., sncabuk@eskisehir.edu.tr
} 


\section{INTRODUCTION}

GIS is a unique tool providing data input and output, storage and management, manipulation and analysis functions (Malczewksi, 1995). Though the early systems were poor in terms of spatial analysis (Rogerson and Fotheringham, 2002), today, its most significant power is the fast, reliable, precise and accurate spatial analysis capabilities. GIS provides commonly used, interdisciplinary, efficient, extensive and versatile tools and methods applicable in different fields (Çabuk, Erdoğan and Çabuk, 2016a). In other words, it has a wide range of capabilities applicable for different areas (Worboys and Duckham, 2004). This is why the popularity of GIS grows rapidly, so does the demand for the geospatial enterprise and workforce (University Consortium for Geographic Information Science [UCGIS], 2006). Depending on the expanding context and aim of its use, dealing with GIS, of which former $\mathrm{S}$ in the abbreviation standing for System has been replaced with Science (Goodchild, 1992), requires different levels of knowledge, skills and competencies, which are of great significance for the success of GIS projects and initiatives (Wikle and Fagin, 2015). Regarding this necessity and the rapid advancements in the geospatial sector (Waters, 2013), there has been a good deal of research on the necessity and content of GIS education and training in different levels as well (Coppock, 1992; Raper and Green, 1992; Rogerson, 1992; Kemp and Frank, 1996; Bednarz and Ludwig, 1997; Foote, 1997; Wikle, 1998; Forer and Unwin 1999; Elwood, 2009; Fagin and Wikle, 2011; Schulze, Kanwischer and Reudenbach, 2013; Wikle and Fagin, 2015; Rickles, Ellul and Haklay, 2017). Along with the education and training debates come also the necessity to define the competencies for GIS jobs, assure competency and integrity among the practitioners, and develop methods of recognition (Albrecht, 1998; Wikle, 1998), so that the sectoral needs can properly be met (PDRI, 2005). Within this context, competency models not only form the basis for professional certification, but also help develop educational/training curricula and criteria for program accreditation (Urban and Regional Information Systems Association [URISA], 2012). Donatelli (2013) states that the competency specifications are most useful as self-assessment instruments that professionals and students can use to identify gaps in their knowledge and skills.

Some of the recent and most known efforts to define GIS competencies at both educational and workplace based context helped the development of the Geographical Information Science and Technology Body of Knowledge (GIS\&T BoK), Geospatial Technology Competency Model (GTCM) and Geospatial Management Competency Model (GMCM). Although criticized from various aspects (Waters, 2013; Rip, Wallentin and van Lammeren, 2014), GIS\&T BoK specifies what current and aspiring geospatial professionals need to know and be able to do (Dibiase, 2007; DiBiase,DeMers, Johnson, Kemp, Luck, Plewe and Wentz, 2007), and has been the basis for most of the curricula development and revision, and educational quality assurance (Prager and Plewe, 2009; DeMers, 2009; Ahearn, Icke, Datta, DeMers, Plewe and Skupin, 2013). The Association of American Geographers published the first edition of GIS\&T BoK, including a hierarchical structure of 10 knowledge areas, 73 units, 329 topics, and 1660 educational objectives, in 2006. The second edition including updates to better use GIS\&T BoK, and presenting useful inputs to fulfill GIS workforce demand (Wallentin, Hofer and Traun, 2015) came in 2016, published online at http://gistbok.ucgis.org/. GIS\&T BoK was taken as a starting point for a project for better aligning Europe's GIS\&T curricula at the academic level, as explained at the project website, conducted with 35 partners from 25 countries (European Union, Geographic Information Need to Know Project, (GI-N2K, 2013). GIS\&T BoK was also an essential source for GTCM, which was developed collaboratively by Employment and Training Administration (ETA), the GeoTech Center, and industry experts, comprising 39 competencies under four groups: technical, analytical, business and interpersonal (Waters, 2013; US Department of Labor's Employment and Training Administration [DOLETA], 2014). GMCM, on the other hand, was issued in 2012 by Urban and Regional Information Systems Association (URISA) and US Department of Labor's Employment and Training Administration (DOLETA), presenting 74 competencies and 18 competency areas. DOLETA also defined new geospatial occupations such as Geospatial Information Scientist and Technologist, Remote Sensing Technician, Geodetic Surveyor, Surveying Technician, Mapping Technician (DiBiase, Corbin, Fox, Francica, Green, Jackson, Gary, Jones, Mennis, Schuckman, Smith and Van Sickle, 2010; Waters, 2013).

Competencies defined within various models or bodies of knowledge also form a basis for the development of professional certification systems, which has been a matter of discussion in the GIS society for more than 25 years (Mathews and Wikle, 2017). UCGIS remarks that much of the debate on the necessity of GIS professional certification has arisen due to semantic misunderstanding, and is often confused with certificates, which are given by the higher education institutions (UCGIS, 2017). Professional certification focuses on the evaluation of the qualifications of GIS practitioners (Obermeyer, 2007). Accordingly, the first attempt to introduce a certification program, namely Certified Mapping Scientists, GIS\&LIS, came in 1991 from the American Society for Photogrammetry and Remote Sensing (ASPRS) (Mathews and Wikle, 2017). However, the most noteworthy advancement was the foundation of GIS Certification Institute (GISCI, 2017); a non-profit organization aimed at the certification of GIS professionals. The certification process comprises a portfolio assessment and an examination developed using the GIS\&T BoK as a significant input. The successful candidates are awarded with the GISP Certificate. Every 5 years, recertification is required. Another professional certification is 
launched by the United States Geospatial Intelligence Foundation (USGIF). The USGIF Universal GEOINT Certification is available in GIS and Analysis Tools, Remote Sensing and Imagery Analysis, and Geospatial Data Management. The knowledge, skills, and abilities critical to the GEOINT workforce defined in GEOINT Essential Body of Knowledge are recognized via this certification (United States Geospatial Intelligence Foundation [USGIF], 2018).

As a protracted EU candidate, Turkey is also a country where GIS education, training, certification and competencies have been a matter of debate especially for the last 10-15 years. Today, there are various institutions and enterprises providing GIS education and training programs. Eskişehir Technical University awards graduate and doctorate degrees. Anadolu University has an e-certificate program in the field of GIS. There are also some other respected universities awarding various degrees in geospatial sciences, like Middle East Technical University, Yıldız Technical University, Ege University etc. However, the education and training context, methods and the workforce GIS skills are often criticized especially in terms of their sufficiency, quality and necessity to meet the sectoral demands and the GIS competencies (Taş, 2006; Yiğit, Ataol and Dinç, 2011; Oflaz, Bayraktar, Köksoy, Iravul, Ölmez, Çabuk, Avdan, Çabuk, Bektöre, Orakoğlu, Çömert, Erdoğan and Tiryakioğlu, 2013; Sarı, 2013; Çabuk, Avdan, Uyguçgil, Çabuk, Erdoğan, Yiryakioğlu, Köksoy and Iravul, 2014; Çabuk and Çabuk, 2015; Uça AvcI, Uça Güneş and Çabuk, 2015; Çabuk et al., 2016a). Considering the rapid advancements in GIS technologies and context, the professional information, skills and competencies need to be continuously improved to assure the quality of the works. The results of a survey conducted by Şeremet and Chalkley (2016) show that the employers point out that the number of GIS related jobs are continuously increasing in Turkey; however, they mostly agree that it is difficult to find qualified staff. Therefore, as Horak (2015) mentions, there is an emerging need to develop a method to "motivate people for continuous education, lead them towards necessary vocational standards and evaluate the professionals' success and achievements", at national, regional and international levels. In Turkey, this need has not yet shown up as the development of a national body of knowledge as in the USA and EU, rather as the development of national vocational standards and qualifications within national qualifications framework.

Consequently, this paper focuses on the Turkish experience of defining the GIS competencies for different level GISrelated jobs and certification applications. Within this context, General Directorate of GIS, Turkish Ministry of Environment and Urbanization, and Earth and Space Sciences Institute of Eskisehir Technical University (former Anadolu University) worked collaboratively for the development of the vocational standards and qualifications for two GIS related jobs between 2013-2016, besides other comprehensive projects comprising online training activities aimed at the dissemination of GIS utilization in the country. Along with the development of the vocational standards ad national qualifications two research projects were also conducted to develop a comprehensive certification system software and quality management system in compatible with the national qualifications system requirements and ISO/IEC 17024 standard (2012). The results and the outputs of the projects are supposed to contribute to the debates on the necessity of GIS certification, quality of the workforce and the continuous learning requirements.

\section{TURKISH NATIONAL VOCATIONAL QUALIFICATIONS SYSTEM}

The first attempts to develop national vocational standards started as a project with the funding support of the World Bank in 1993 and continued until 2000. Among the targets of the project were to provide the incompetent laborers with vocational trainings and employment, and to develop vocational standards and certification systems. Turkish Standards Institution led the process for the development of approximately 100 vocational standards. In 2006, Vocational Qualifications Institution (MYK) was established under the Ministry of Labor and Social Security to take over this mission along with some other major responsibilities (Çabuk, Erdoğan and Çabuk, 2016b).

Turkish national qualifications are developed based on either national or international vocational standards. MYK defines the national vocational standards as the documents clarifying the definition, working environment and conditions, level, required minimum knowledge, skills and competences for the vocations. They also constitute the basis of academic, vocational and technical training and education programs. This structure somewhat looks similar to the competency models in USA. However, the information, skills and the competencies contained in the national qualifications are not as much detailed as the ones in the GIS\&T BoK, which is also used as an input during the test based examination for GISP Certification. This is because GIS is not considered as one unique profession. Rather, it is accepted as an extensive area bearing a wide range of related vocations. Thus, Turkish Vocational Qualifications Framework focuses on the definition of a variety of GIS-related jobs that the sector needs with different levels of competencies. The levels of the standards are determined in accordance with the European Qualifications Framework (EQF), which provides mutual understanding and recognition of qualifications across different countries in Europe. As explained by European Centre for the Development of Vocational Training (CEDEFOP, 2018), EQF describes the qualifications at eight different levels, each level based on learning outcomes in terms of knowledge, skill, and responsibility and autonomy descriptors. Figure 1 summarizes the general structure of a vocational standard. 

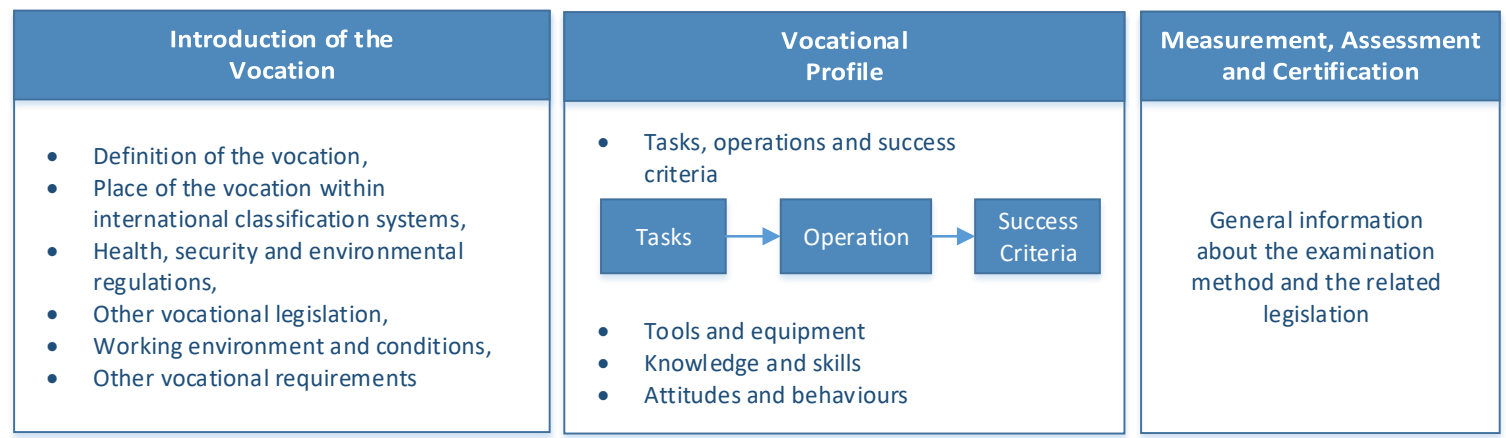

Figure 1: Basic Structure of Vocational Standards

National vocational qualifications, on the other hand, are the reference documents setting the measurement and assessment, recertification, review and other necessary certification requirements, including the basic criteria for the examiners. The general structure of a national vocational qualification is represented in Figure 2. National vocational qualifications determine the process and requirements for personnel certification in order to ensure a quality assurance framework for the labor market, employees and the public. The certification methods are uniquely put forward for each vocation. Some are only competency and test based, some also require assessment of portfolios and work experience. In the case of GIS, currently published Turkish qualifications necessitate to take examinations through which the information, skills and competencies are assessed. Work experience and evidences of continuous learning achievements are only taken into consideration for review and recertification processes.

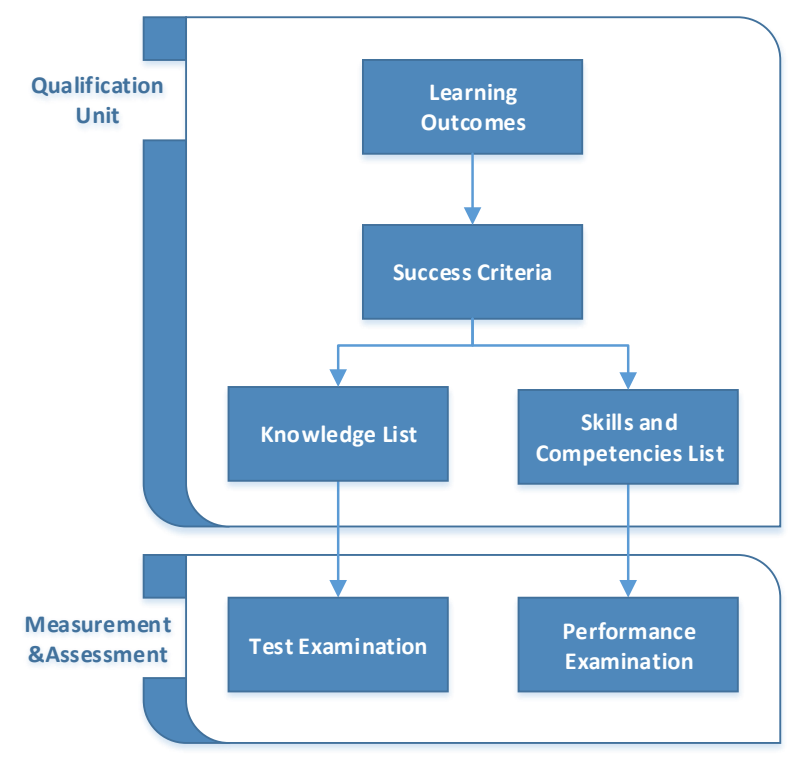

Figure 2: Basic Structure of National Qualifications

Both vocational standards and national vocational qualifications are developed in accordance with the "Regulation on the Development of National Vocational Standards and National Qualifications" through a participatory process, and regularly revised every 5 years. Development of a standard/qualification usually starts with an application from the demanding organization. MYK, then, executes the necessary investigations and assigns the proper organization (either the applicant or another related institution) to develop standards and qualifications, in case the application is approved. Draft documents are shared with related parties and the public prior to their validation by the related Sector Committee. The process is finalized with the publication of the validated standards/qualifications. Up to now, MYK issued 792 vocational standards from level 2 to 7 , and 451 national qualifications from level 2 to 6 , under 26 different sectors such as justice and security, energy, finance, education, environment, information technologies, mining, health and social services, construction, tourism, agriculture etc. Table 1 gives a comparison of vocational standards and national qualifications.

Table 1: Comparison of Vocational Standards and National Qualifications 


\begin{tabular}{|c|c|c|}
\hline 感 & $\begin{array}{l}\text { They are developed in accordance with the primary needs } \\
\text { of labour market and education organizations as well as } \\
\text { advices of MYK Sector Committees. }\end{array}$ & $\begin{array}{l}\text { They are developed basing either on national vocational standards } \\
\text { or international vocational standards in case the former does not } \\
\text { exist. }\end{array}$ \\
\hline$\cdot \frac{E}{4}$ & $\begin{array}{l}\text { They explain the work standards necessary for the } \\
\text { performance of the jobs. }\end{array}$ & $\begin{array}{l}\text { They explain the knowledge, skills and competences as well as their } \\
\text { measurement and assessment methods, in accordance with the } \\
\text { standards. }\end{array}$ \\
\hline 艺 을 & \multicolumn{2}{|c|}{$\begin{array}{l}\text { Drafts are developed through a participatory and collaborative process and shared with the related bodies and the public. } \\
\text { Drafts are evaluated by MYK Sector Committees and presented to MYK Executive Board. }\end{array}$} \\
\hline 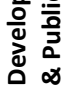 & $\begin{array}{l}\text { Upon MYK Executive Board approval, standards are } \\
\text { published in the Official Gazette. }\end{array}$ & Upon MYK Executive Board approval, qualifications are in force. \\
\hline
\end{tabular}

One of the most essential components of the system is clearly the certification process, which is performed by the authorized certification bodies in the country. MYK gives authorization to the eligible applicants after a comprehensive process including external audits. In the first place, the intended certification bodies are asked to submit a preliminary application to MYK resulting in signing a preliminary authorization agreement for the successful ones. In accordance with the preliminary agreement, the applicants should establish a quality management system that is compatible with ISO/IEC 17024 standard and get accreditation from the Turkish Accreditation Agency (Turkak). Once accredited by Turkak, MYK conducts an audit, through which the successful applicants are granted "authorization for certification" in the field of intended national qualifications.

\section{MATERIALS AND METHODS}

The fact that the number of the qualified technical personnel to perform GIS jobs is inadequate and the efficient use of GIS technologies amongst the currently employed GIS professionals is unfortunately insufficient, revealed the necessity to start a comprehensive project by the General Directorate of GIS, Ministry of Environment and Urbanization, to find proper solutions to overcome this gap. Accordingly, the Ministry started a series of projects and mutual collaborations to disseminate the GIS use in the country. The main approach for this dissemination framework had two main sections (Figure 3). The first section focused on the development of GIS related national vocational standards and national qualifications, and establishment of personnel certification infrastructure for the GIS qualifications in compatible with MYK regulations and ISO/IEC 17024 standard (Conformity Assessment - General Requirements for Bodies Operating Certification of Persons). The second section of the project embraced the development of a distance-learning model as well as distance/open training activities, so that current employees of the Ministry would be trained and a continuous learning infrastructure/asset would be established.

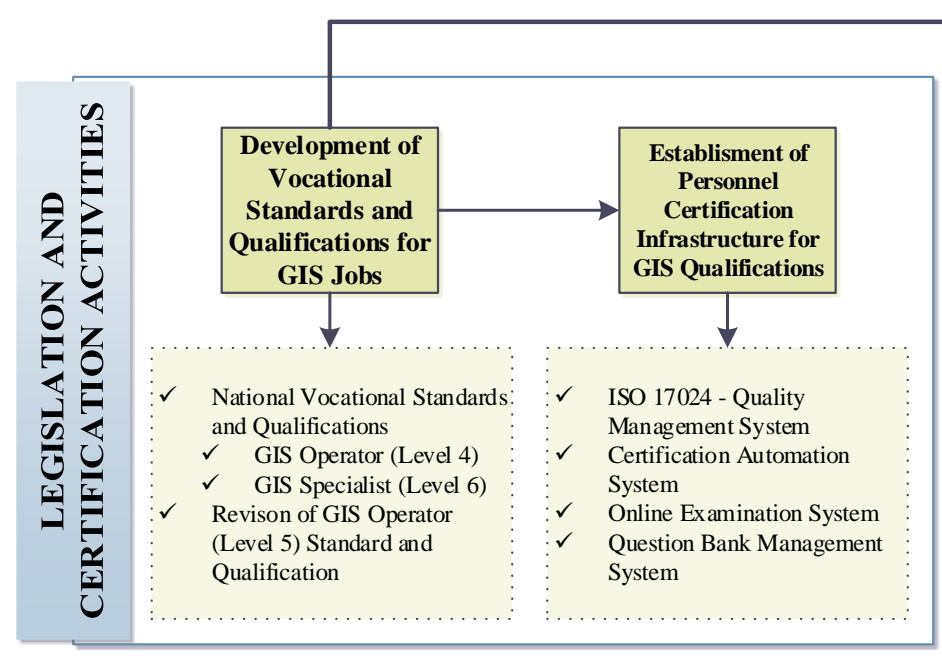

Section I

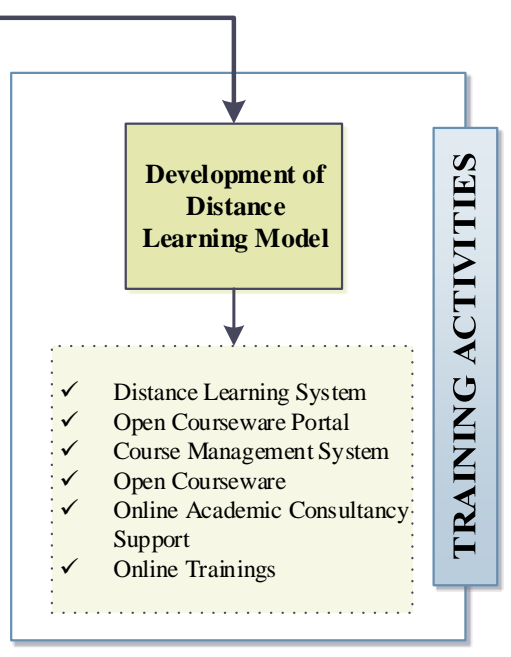

Section II

Figure 3: Structure of Dissemination of GIS Use and Capacity Project (Çabuk et al., 2016b)

The activities of Section I, which also constitutes the main context of this paper, can be classified under three main relevant work phases. The first phase is the development of vocational standards and national qualifications for GIS 
related jobs. The second phase embraces a research project during which a certification system and a software was developed. The last phase was again conducted within a research project focusing on the online examination system and question bank development. In this part of the study, the main materials and the methods of these three phases of Section I are briefly explained.

\section{Development of Vocational Standards and National Qualifications}

The first phase included the development of the vocational standards and the national qualifications for GIS Operator (Level 4) and GIS Specialist (Level 6) with the participation of 12 team members from Eskisehir Technical University and the Ministry of Environment and Urbanization. The draft vocational standards were also evaluated during a workshop including the participation of professionals from 31 organizations such as universities, governmental organizations, nongovernmental organizations, chambers etc. on 7th November 2013. The national qualifications development team was assigned for the development of the GIS Operator (Level 4) and GIS Specialist (Level 6) national qualifications, including 33 professionals from relevant stakeholders such as General Directorate of GIS, Eskisehir Technical University, Afyon Kocatepe University, i̇stanbul Technical University, Bülent Ecevit University, Aksaray University, Hacettepe University, Ankara University, ISPARK, UGETAM A.S. and TURKSAT. The method of the process mainly based on the detailed research and investigation of the sectoral needs and GIS competencies both in national and international levels, as well as the collaborative discussions on the requirements defined within the national vocational qualifications system. Besides, as in any standard development process, one of the eminent pillars of the methodology inevitably depended on the workshops held in a multidisciplinary environment, feedback collections and evaluations on the draft documents. The national and international GIS training and education curriculum, approaches on the certification applications, competency model development processes and output have been among the major material for the development of the national standards and qualifications. The activities of the national qualifications development stage can be summarized as follows:

- A protocol was signed on 31st July 2013 between the Ministry of Environment and Urbanization, General Directorate of GIS, and MYK for the development of GIS Operator (Level 4) and GIS Specialist (Level 6) national qualifications.

- A team of 28 members from the Ministry, universities and other institutions was built for the development of national qualifications.

- The team members attended the national qualification development training on 17th September 2014 given by MYK.

- The draft national qualifications were prepared, evaluated with the team members on 15th January 2015 and revised according to the feedbacks.

- The last draft documents were sent to MYK on 3rd February 2015 for further processes such as public share and feedback collection.

- The national qualifications were approved and published on 25th May 2016.

\section{Development of Certification System and Software}

The second and third phases of the study focused respectively on the development of a certification system (software) and an online examination software in compatible with the requirements put forward by MYK, relevant legislation, ISO/IEC 17024 standard and the administrative context of the ministry. The second phase was completed in 4,5 months (between 1st September - 15th December 2015) and the project team was made up of 11 professionals from the University, as well as the BelgeCBS personnel, who had experience, knowledge and skills in the related fields such GIS, information technologies and personnel certification/quality management systems. The development of the online examination system and questions lasted 3 months and was completed at the end of March 2016.

To fulfill the needs of these phases the followings were realized during the projects:

- Examination of the vocational standards and national qualifications (GIS Operator and GIS Specialist),

- Examination of the national qualifications system requirements and relevant MYK regulations,

- Examination of the requirements clarified in ISO/IEC 17024 standard,

- Examination of the administrative status, technical infrastructure and resources of the General Directorate of GIS, Ministry of Environment and Urbanization,

- On-site surveys and analysis to physically and administratively determine the certification system requirements of the Ministry, 
- Determination of organization structure, sources, personnel and legal basis of the establishment of the certification unit,

- Development of quality management system and documentation,

- Development of the certification software with comprehensive capabilities of the certification process (application submission, application control and approval, examination organization, decision on certification, appeal and complaint management, quality system and documentation management etc.),

- Development of online examination software and question bank management module in compatible with the certification software

- Trainings for the established systems and the software,

- Software tests and certification system controls on sample tests and processes

- Feedback collections and evaluations of the control results

- Updates and revisions.

\section{RESULTS}

\section{Vocational Standards and National Qualifications for GIS-related Jobs}

The first GIS related vocational standard in Turkey, GIS Operator (Level 5), was issued in 2009 followed by the publication of national qualifications in 2012. However, this was not enough to meet the sectoral needs, and the documents were criticized for degrading the vocational knowledge, skills and competencies to one specific working area (natural gas operations). To overcome the problems of GIS dissemination in the country, and to enhance the GIS related qualifications framework, General Directorate of GIS applied MYK to demand the development of GIS Operator (Level 4) and GIS Specialist (Level 6) vocational standards, and revision of GIS Operator (Level 5). The major project partner was the Earth and Space Sciences Institute of Eskisehir Technical University (former Anadolu University). The vocational standards were approved by the related Sector Committee of MYK and published in the Official Gazette on 6th June 2014. The national qualifications were published on 25th May 2016. Table 2 summarizes the basic outlines of the GIS Operator (Level 4), Table 3 gives basic information for GIS Specialist (Level 6) qualifications.

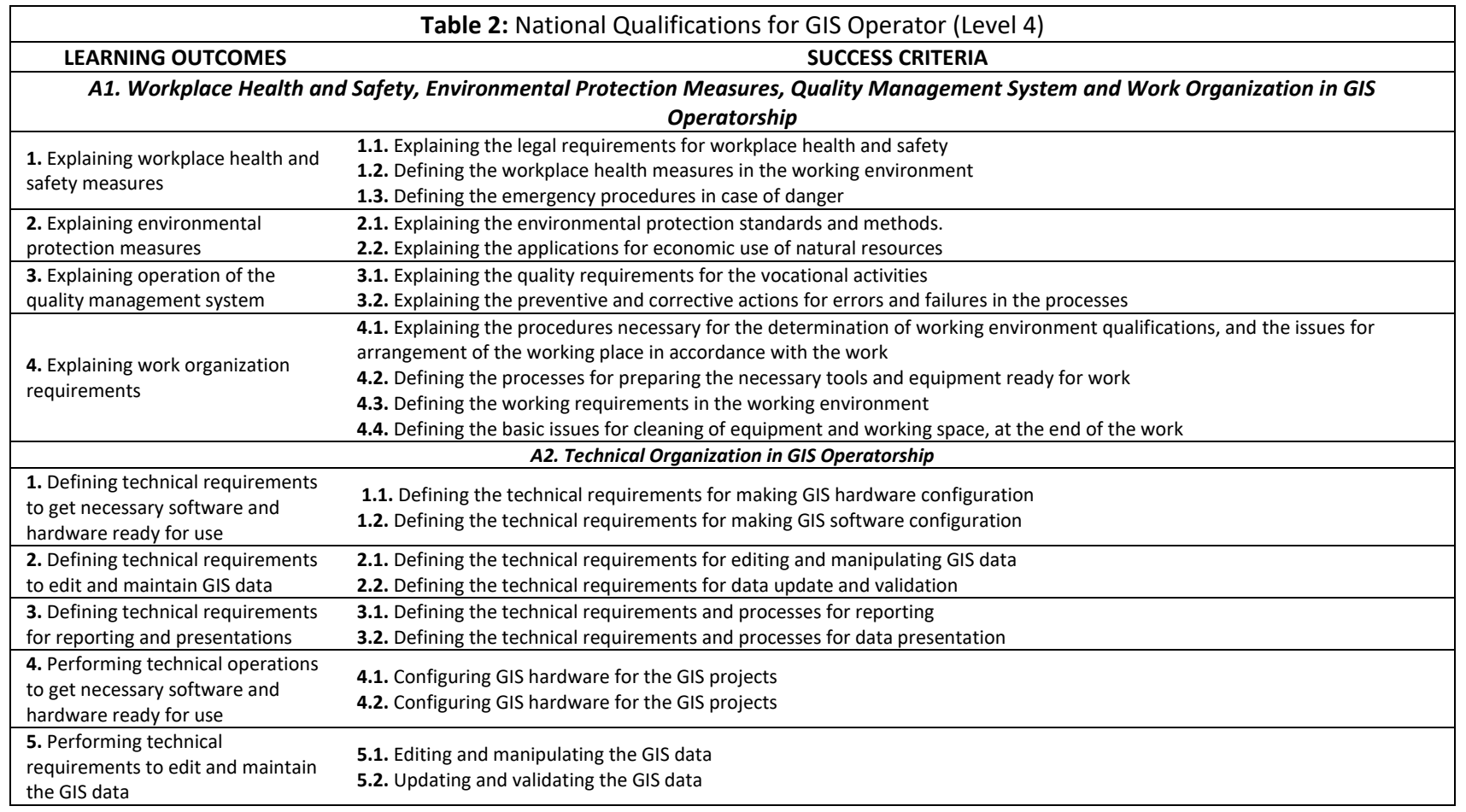

Table 3: National Qualifications for GIS Specialist (Level 6) 


\begin{tabular}{|c|c|}
\hline \multicolumn{2}{|c|}{ A1. Workplace Health and Safety, Environmental Protection Measures, Quality Management System and Work Organization in GIS Specialty } \\
\hline $\begin{array}{l}\text { 1. Explaining workplace health } \\
\text { and safety measures }\end{array}$ & $\begin{array}{l}\text { 1.1. Explaining the risk factors and risk minimization requirements related to workplace health and safety } \\
\text { 1.2. Defining the workplace health and safety measures in the working environment } \\
\text { 1.3. Defining the emergency procedures in case of danger }\end{array}$ \\
\hline $\begin{array}{l}\text { 2. Explaining environmental } \\
\text { protection measures }\end{array}$ & $\begin{array}{l}\text { 2.1. Defining the environmental impacts and potential threats related to working environment and } \\
\text { operations } \\
\text { 2.2. Explaining the environmental protection measures regarding potential environmental impacts and } \\
\text { threats during work } \\
\text { 2.3. Explaining the basic requirements related to efficient use of business resources such as energy, } \\
\text { consumables and time }\end{array}$ \\
\hline $\begin{array}{l}\text { 3. Explaining operation of the } \\
\text { quality management system }\end{array}$ & $\begin{array}{l}\text { 3.1. Explaining the quality requirements and technical procedures to provide quality for the work } \\
\text { 3.2. Explaining the preventive and corrective actions for errors and failures in the processes }\end{array}$ \\
\hline $\begin{array}{l}\text { 4. Explaining work organization } \\
\text { requirements }\end{array}$ & $\begin{array}{l}\text { 4.1. Explaining the requirements for work plan creating process regarding to demands/needs } \\
\text { 4.2. Defining the necessary procedures for creating work plans } \\
\text { 4.3. Explaining the personnel planning requirements related to work } \\
\text { 4.4. Explaining the procedures necessary for the determination of working environment qualifications, and } \\
\text { the issues for arrangement of the working place in accordance with the work } \\
\text { 4.5. Defining the circumstances and requirements for communicating with other professionals for works } \\
\text { outside his/her responsibility }\end{array}$ \\
\hline \multicolumn{2}{|r|}{ A2. Information Security in GIS Specialty } \\
\hline $\begin{array}{l}\text { 1. Defining data and information } \\
\text { security requirements }\end{array}$ & $\begin{array}{l}\text { 1.1. Listing the basic items related to information security standards } \\
\text { 1.2. Defining the confidentiality process within information security standards } \\
\text { 1.3. Defining the integrity process within information security standards } \\
\text { 1.4. Defining the availability process within information security standards }\end{array}$ \\
\hline $\begin{array}{l}\text { 2. Defining the development of } \\
\text { in-house security policy } \\
\text { regarding the GIS project }\end{array}$ & $\begin{array}{l}\text { 2.1. Listing the major subjects to be comprised within security policy } \\
\text { 2.2. Listing the procedures for approval and implementation of security policy } \\
\text { 2.3. Explaining the methods to ensure that the security policy works }\end{array}$ \\
\hline \multicolumn{2}{|r|}{ A3. Technical Organization in GIS Specialty } \\
\hline $\begin{array}{l}\text { 1. Interpreting technical } \\
\text { requirements to get necessary } \\
\text { software and hardware ready } \\
\text { for use }\end{array}$ & $\begin{array}{l}\text { 1.1. Interpreting the requirements for preparing the necessary hardware and network configuration for the } \\
\text { GIS project } \\
\text { 1.2. Interpreting the requirements for preparing the necessary software configuration for the GIS project }\end{array}$ \\
\hline $\begin{array}{l}\text { 2. Interpreting technical } \\
\text { information to conduct } \\
\text { operations for the GIS project }\end{array}$ & $\begin{array}{l}\text { 2.1. Interpreting the necessary processes to obtain data } \\
\text { 2.2. Explaining the requirements for editing and manipulating data } \\
\text { 2.3. Interpreting the necessary processes for the determination of methods to transform the data into } \\
\text { information } \\
\text { 2.4. Listing the necessary processes for performing data query and analysis } \\
\text { 2.5. Explaining national and international legislation and standards related to GIS }\end{array}$ \\
\hline $\begin{array}{l}\text { 3. Defining technical } \\
\text { requirements for reporting and } \\
\text { presentations }\end{array}$ & $\begin{array}{l}\text { 3.1. Defining the technical requirements and processes for reporting } \\
\text { 3.2. Describing the technical requirements and processes for data and information presentations }\end{array}$ \\
\hline $\begin{array}{l}\text { 4. Performing technical } \\
\text { operations to get necessary } \\
\text { software and hardware ready } \\
\text { for use }\end{array}$ & $\begin{array}{l}\text { 4.1. Configuring GIS software for the GIS projects } \\
\text { 4.2. Configuring GIS hardware and network for the GIS projects }\end{array}$ \\
\hline $\begin{array}{l}\text { 5. Performing technical } \\
\text { operations to conduct the GIS } \\
\text { project }\end{array}$ & $\begin{array}{l}\text { 5.1. Providing the obtainment of data } \\
\text { 5.2. Providing the editing and manipulation of data } \\
\text { 5.3. Determining the methods to transform data into information } \\
\text { 5.4. Querying and analyzing the data } \\
\text { 5.5. Preparing web services }\end{array}$ \\
\hline $\begin{array}{l}\text { 6. Reporting and making } \\
\text { presentation }\end{array}$ & $\begin{array}{l}\text { 6.1. Realizing reporting process } \\
\text { 6.2. Realizing data and information presentation process }\end{array}$ \\
\hline
\end{tabular}

\section{Certification Process and System}

Certification in general is part of conformity assessment, which is done for products, processes, services and most recently persons (Kelly, 2007). ISO/IEC 17024 standard (2012) defines the certification of persons as one of the means of providing assurance that the certified person meets the requirements of the certification scheme (International Standardization Organization [ISO], 2012). From this aspect, personnel certification is a means of quality assurance for the labor market. The basis of the national certification process, in other words the vocational qualifications, ensured continuous improvement and lifelong learning opportunities. They also constitute a bridge between vocational education/training environment (Young, 2005) and the labor market. Especially in the field of GIS, the advancements are fast and extensive; the concepts and methods applied are improving. Hence, dealing with GIS inevitably requires continuous professional development (CPD). Buckley and Donert (2004) emphasize the definition made by the Association of Geographical Information (AGI) to explain CDP as "the systematic maintenance, improvement and broadening of knowledge and skill, and the development of personal qualities necessary for the execution of professional and technical duties throughout one's working life". Vocational certificates are awarded for a limited time and review 
(surveillance) and recertification processes are requisite to continue their validity. In that respect, a vocational certification system is also a useful means for CDP. For example, both GIS Operator (Level 4) and GIS Specialist (Level 6) certificates are valid for 5 years. Recertification requires either a performance examination covering the skills and competencies explained in the national vocational qualifications or the assessment of the portfolios of the certificate holders. During the validity period of the certificates, a review process based on the assessment of records such as work experience, involvement in GIS projects, academic contributions etc. is mandatory, which ends up with the suspension of the certification for those who are unsuccessful. This structure inevitably motivates the certificate holders to catch up with the advancements in the field of GIS, and thus continue their professional development.

As the national authority charged with the responsibility of disseminating and improving GIS utilization in the country, the General Directorate of GIS, also decided to carry out the certification processes. Thus, a GIS Certification Body, namely BelgeCBS, was established under the General Directorate in September 2015. The major necessity to become an authorized certification body is the establishment of the personnel certification system. Table 4 summarizes the main phases and the related activities realized during the establishment of BelgeCBS.

\begin{tabular}{|c|c|}
\hline \multicolumn{2}{|r|}{ Table 4: Establishment of BelgeCBS } \\
\hline PHASE & ACTIVITIES \\
\hline 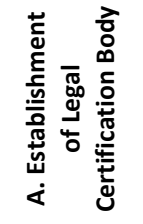 & $\begin{array}{l}\text { 1.BelgeCBS was legally established under the General Directorate of GIS, organization structure was determined and } \\
\text { required personnel was assigned. } \\
\text { 2. The aim, responsibilities, competencies and missions of BelgeCBS were clarified through its approved circular. } \\
\text { 3. BelgeCBS's procedures and precautions to ensure impartiality were defined. }\end{array}$ \\
\hline 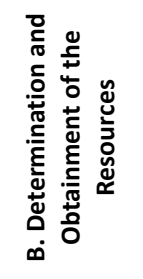 & $\begin{array}{l}\text { 1. As clarified in the circular, the financial and physical sustainability of BelgeCBS was ensured to be provided by the } \\
\text { Ministry of Environment and Urbanism. } \\
\text { 2. An examination space equipped with the necessary hardware and software in compatible with the national } \\
\text { qualifications and MYK regulations was structured. } \\
\text { 3. The number and the qualifications of the required human resources such as examiners, invigilators, question writers, } \\
\text { committee members were determined. The personnel were assigned and trained. } \\
\text { 4. A software (BelgeCBS Certification Automation) was developed and installed for performing the certification } \\
\text { activities, question bank management, examination organization and quality system management. }\end{array}$ \\
\hline 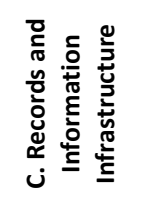 & $\begin{array}{l}\text { 1. A procedure for keeping the records was determined. Most of the records were planned to be archived digitally. } \\
\text { (BelgeCBS Certification Automation provides infrastructure for digitally keeping and maintaining the records.) } \\
\text { 2. BelgeCBS web site was designed and published to give objective, impartial and transparent public information about } \\
\text { the certification procedures and examinations. } \\
\text { 3. Security measures and procedures for both the examination materials and the spaces were defined. } \\
\text { 4. Various types of agreements were prepared to clarify security regulations. }\end{array}$ \\
\hline 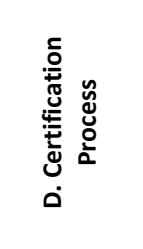 & $\begin{array}{l}\text { 1. Questions for test and performance examination were prepared, controlled and approved by the Program } \\
\text { Committee. } \\
\text { 2. Draft examinations were designed, structured and tested multiple times both to check the conformity to national } \\
\text { qualifications, MYK regulations and certification automation capabilities. } \\
\text { 3. BelgeCBS Certification Automation was tested to check the application, assessment, examination, decision process } \\
\text { etc. } \\
\text { 4. BelgeCBS logo was created and the conditions of logo uses was documented. }\end{array}$ \\
\hline 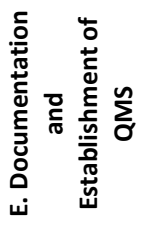 & $\begin{array}{l}\text { 1. All the necessary procedures and processes were documented in accordance with ISO } 17024 \text { standard and MYK } \\
\text { requirements. } \\
\text { 2. A quality management system (QMS) fulfilling the requirements such as management system documentation, control } \\
\text { of records, management review, internal audit, corrective and preventing actions was developed. }\end{array}$ \\
\hline
\end{tabular}

Upon completion of the accreditation processes BelgeCBS was accredited by Turkak in October 2017, in the field of GIS Operator (Level 4) and GIS Specialist (Level 6) national qualifications. However, due to an ongoing lawsuit against the execution of GIS Specialist (Level 6) Vocational Standard, the authorization for certification was granted only for GIS Operator (Level 4), by MYK, in June 2018.

Besides various criticism and oppositions, of which some are only disruptive rather than focusing on improvement and enhancement for the benefit of all the parties, the expected outcomes of the system include the followings:

- Well defined education programs,

- Well defined GIS jobs in harmony with education programs and sectoral needs, 
- Enhanced relations between labor market, education institutions and the personnel,

- Employment of qualified personnel,

- Good quality and sustainable works, projects and services,

- Efficiency in public and private GIS sector,

- Continuous improvement,

- Quality assurance.

As an important out of the research process the certification process is based on the utilization of a modular certification software. The main modules and functions of the software is summarized in Table 5.

\begin{tabular}{|c|c|}
\hline \multicolumn{2}{|c|}{ Table 5: Certification System Software Capabilities } \\
\hline Quality Management Module & Certification Process Management Module \\
\hline $\begin{array}{c}\text { Management of new document, revision, cancellation, publishing } \\
\text { demands } \\
\text { Management of records } \\
\text { Management of outsourced documents } \\
\text { Management of corrective and preventive actions }\end{array}$ & $\begin{array}{c}\text { Definition of certification programs } \\
\text { Definition of certification examination (location, date, context, software } \\
\text { etc.) } \\
\text { Monitoring and approval of certification examination submissions } \\
\text { Management of appeal and complaint processes } \\
\text { Management of decision on certification } \\
\text { Management of certification cancellation and suspension }\end{array}$ \\
\hline Question Bank Module & Examination Organization Module \\
\hline $\begin{array}{c}\text { Question writing } \\
\text { Question control, approval and revision } \\
\text { Preparation of master question list for the examinations } \\
\text { Reporting the performance of question writers } \\
\text { Reporting the performance of the question }\end{array}$ & $\begin{array}{c}\text { Organization of the examination } \\
\text { Definition of examination and examiner information } \\
\text { Assignment of the examiners, places and the sessions } \\
\text { Listing examinee information } \\
\text { Online examination } \\
\text { Online examination result management }\end{array}$ \\
\hline
\end{tabular}

\section{CONCLUSIONS AND DISCUSSIONS}

Today, GIS has become an inevitable asset and a significant field of science and technology. Geospatial professions cross boundaries of the geospatial industry sectors and overlap one another (Dibiase, 2012). In this context, it is also discussed whether it is a profession or not (Obermeyer, 1994; Obermeyer, 2007; Dibiase, 2012). All the way, it is an undeniable fact that the need for GIS education/training and qualified personnel in the sector is considerably increasing. Kemp (2003) highlights the need to establish exactly what GIS professionals should know and be able to do, and touches on the importance of both accreditation of GIS programs and certification of GIS professionals. Mulaku (2013) underlines the wide array of GIS skill sets, which necessitates a standardization for the benefit of the GIS industry. GIS\&T BoK, GTCM, GMCM, GISP certification, USGIF Universal GEOINT Certification and GI-N2K project have become pioneer attempts in this field.

In Turkey, too, the need for quality assurance for GIS related jobs and personnel resulted in the development of vocational standards and national vocational qualifications for three GIS related jobs. The structure of the system, however, is quite different from the models and body of knowledge in the United States. The certification applications in USA, such as GISP and GEOINT certification, seem to recognize one unique GIS profession and disregard the areas of expertise illustrated in Figure 4. From this point, Turkish National Vocational Qualifications System resembles the vocational qualifications systems in Europe, especially Scotland. Rather than defining only one unique competency model in different tiers, it focuses on the definition of knowledge, skills, competencies, attitudes and behaviors for each vocational area developed in harmony with EQF and its levels. With this structure, it becomes possible to define the role and capabilities, and provide certification for each different overlapping geospatial profession separately (Figure 4). No doubt that this brings along the discussions about whether such a diversity of jobs is really necessary and what should be the limits of it. Still, vocational certification provides a unique opportunity for CDP and thus, supports the lifelong learning strategy.

Instead of the context, the major criticism seems to be continuing on the necessity of the certification especially for graduates of some specific BSc programs, and the eligibility criteria of the examiners. A good example to this is the current lawsuit against GIS Specialist (Level 6) qualifications filed by the Chamber of the Surveying and Cadastral Engineers, which indirectly claims that the members of the profession are already GIS specialists since the major knowledge and competencies defined in the national qualifications comprise the academic learning outcomes. The direct claim on the other hand emphasize that the knowledge, skills and competencies put forward by "GIS Specialist (Level 6)" classifies this profession as a field of engineering, within which MYK has no legal rights to develop a vocational standard. However, this 
approach is most likely to ignore all the respected discussions, research and studies on the status, needs and deep context of GIS, and frames GIS as an outcome of one specific academic program.

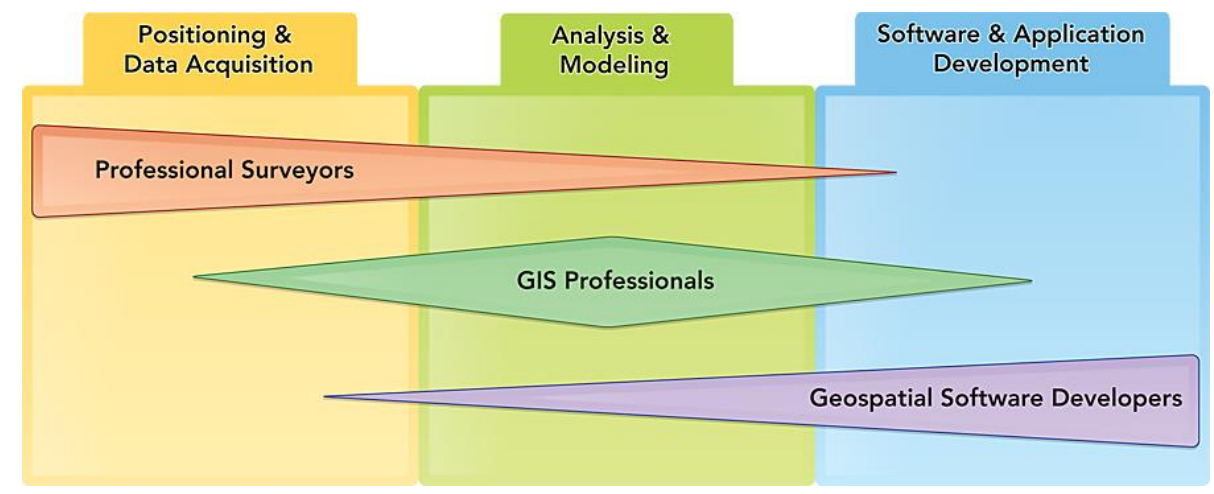

Figure 4: The Work Role of Geospatial Professions (DiBiase, 2012).

During the development process of the vocational standards and the national qualifications, national and international examples were investigated. However, GIS\&T BoK, GTCM, GMCM, GISP certification frame etc. should be further analyzed for the improvement of the qualifications and their applicability. Though it does not fit in with the strict MYK formats, certification methods based on the educational background and work experience besides examinations could be taken as a sample for a more qualified certification process.

\section{Acknowledgments}

I thank the members of the scientific research projects conducted under Anadolu University; respectively, "Uzaktan Eğitim Çalışmalarında Açık Ders Malzemeleri Hazırlamak İçin Kullanılabilecek Ders Malzemesi Hazırlama Editörü Geliştirilmesi (Development of Open Courseware Preparation Editor for Distance Education works / Project No:1605F332)", and "Coğrafi Bilgi Sistemleri Kullanımının Yaygınlaştırılması İçin Belgelendirme ve Online Sınav Otomasyonunun Geliştirilmesi (Development of Certification and Online Examination Automation for the Dissemination of GIS Use / Project No: 1605E270). I also thank the member of the research project realized in collaboration with Yersis Analiz Modelleme Eğitim Danışmanlık Hizmetleri San. Tic. Ltf. Şti., namely” Coğrafi Bilgi Sistemleri Alanında Mesleki yeterlilik Kapasitesinin arttırılmasına Yönelik Sistem Tasarımı ve Yazılım Çözümleri (System Design and Software Solutions for Increasing the Vocational Qualifications Capacity in the Field of Geographical Information Systems) for their support during the development of the national qualifications for GIS related jobs and certification processes.Lastly, I thank the managers and personnel of the General Directorate of GIS, Ministry of Environment and Urbanization.

\section{References}

Ahearn, S. C., Icke, I., Datta. R., DeMers, M. N., Plewe, B. \& Skupin, A. (2013). Re-engineering the GIS\&T body of knowledge. International Journal of Geographical Information Science, 27(11), 2227-2245.

Albrecht, J. (1998). Issues in the qualification and certification of geoinformation personnel Proceedings of the Tenth Colloquium of the Spatial Information Research Centre (pp. 16-9). Dunedin: Spatial Information Research Centre. Retrieved January 10, 2019, from $h t t p: / / c i t e s e e r x . i s t . p s u . e d u / v i e w d o c / d o w n l o a d ? d o i=10.1 .1 .528 .4874 \&$ rep=rep1\&type=pdf

Bednarz, S.W. \& Ludwig, G. (1997). Ten things higher education needs to know about GIS in primary and secondary education. Transactions in GIS, 2, 123-133.

Buckley, C. \& Donert, K. (2004). Evaluating e-learning courses for continuing professional development using the Conversational Model: A review of UNIGIS. European Journal of Open, Distance and E-Learning, 7(2). Retrieved January 10, 2019, from http://www.eurodl.org/materials/contrib/2004/Buckley_Donert.pdf.

Çabuk, A. \& Çabuk, S.N. (2015). Yükseköğrenim ve mesleki yeterlilik çerçevesi kapsamında coğrafi bilgi sistemlerine ilişkin ulusal meslek hiyerarşisinin tanımlanması üzerine bir öneri. Harita Teknolojileri Elektronik Dergisi, 7(3), 45-52.

Çabuk, A., Avdan, U., Uyguçgil, H., Çabuk, S. N., Erdoğan, E., Tiryakioğlu, I., Köksoy, E. \& İravul, Y. (2014). CBS eğitimi için uzaktan eğitim destekli bir pilot uygulaması. 7. Ulusal Mühendislik Ölçmeleri Sempozyumu'nda sunulmuştur. Çorum, Turkey.

Çabuk, S. N., Erdoğan, S. \& Çabuk, A. (2016a). Using distance learning methods for increasing geographical information systems utilization capacity. Turkish Online Journal of Education Technology, Special Issue for INTE2016, 1283-1290.

Çabuk, S. N., Erdoğan, S. \& Çabuk, A. (2016b). Vocational qualifications and certification system development for GIS jobs: ministry of environment and urbanization case. Turkish Online Journal of Education Technology, Special Issue for INTE2016, 1309-1317. 
CEDEFOP, (2018). European qualifications framework (EQF). Retrieved November 22, 2018, from http://www.cedefop.europa.eu/en/events-and-projects/projects/european-qualifications-framework-eqf.

Coppock, J. T. (1992). GIS education in Europe. International Journal of Geographical Information Systems, 6(4), 333-335.

DeMers, M. N. (2009). Using intended learning objectives to assess curriculum materials: The UCGIS body of knowledge. Journal of Geography in Higher Education, 33(1), 70-S77.

DiBiase, D. (2007). Is GIS a Wampeter? Transactions in GIS, 11, 1-8.

DiBiase, D. (2012). Strengthening the GIS profession. Retrieved August 14, 2017, ArcNews Summer 2012, ESRI. http://www.esri.com/news/arcnews/summer12articles/strengthening-the-gis-profession.html.

DiBiase, D., Corbin, T., Fox, T., Francica, J., Green, K., Jackson, J., Gary, J., Jones, B., Mennis, J., Schuckman, K., Smith, C. \& Van Sickle, J. (2010). The new geospatial technology competency model: Bringing workforce needs into focus. Journal of the Urban Regional Information Systems Association, 22(2), 55-72.

DiBiase, D., DeMers, M., Johnson, A., Kemp, K., Luck, A.T., Plewe, B. \& Wentz, E. (2007). Introducing the first edition of geographic information science and technology body of knowledge. Cartography and Geographic Information Science, 34(2), 113-120.

DOLETA, (2014). Geospatial Technology Competency Model. Retrieved August 10, 2017, https://www.careeronestop.org/CompetencyModel/competency-models/pyramid-download.aspx?industry=geospatialtechnology.

Donatelli, D. (2013). The core GIS incompetencies: identity, gender, big data, and ineptness in the cloud. The Cartographic Journal, 50(2), 192-196.

Elwood, S. (2009). Participatory action research in geographic teaching, learning and research. Journal of Geography in Higher Education, 33(1), 51-65.

Fagin, T.D. \& Wikle, T. A. (2011). The instructor element of GIS instruction at US colleges and universities. Transactions in GIS, 15(1), 115.

Foote, K.E. (1997). The Geographer's craft: Teaching GIS in the web. Transactions in GIS, 2, 137-150.

Forer, P. \& Unwin, D. (1999). Enabling progress in GIS and education. In P. Longley, M.F. Goodchild, D.J. Maguire, D. Rhind, Geographical information systems: Management issues and applications, 2nd edn., Volume 2, (pp 747-757), New York:John Wiley \& Sons.

GI-N2K, (2013-2016). Geographic information: need to know, the project. Retrieved August 10, 2017, from http://www.gi-n2k.eu/theproject/.

GIS Institute, (2017). What is the GISP? Retrieved May 10, 2017, from https://www.gisci.org/Students/AbouttheProgram.aspx.

Goodchild, M.F. (1992). Geographical Information Science. International Journal of Geographical Information Systems, 6(1), 31-45.

Horák, J. (2015). The role of certification in GIS\&T education. Procedia - Social Behavioral Sciences, 174, 1356-1363.

International Standardization Organization, (2012). ISO/IEC 17024: 2012. Conformity Assessment - General Requirements for Bodies Operating Certification of Persons.

Kelly, W.E. (2007). Certification and accreditation in civil engineering. Journal of Professional Issues in Engineering Education and Practice, 133(3), 181-187.

Kemp, K.K. \& Frank, A.U. (1996). Toward consensus on a European GIS curriculum: the international post-graduate course on GIS. International Journal of Geographical Information Systems, 10(4), 477-497.

Kemp, K.K. (2003). Why GIS professional certification matters to all of us. Transactions in GIS, 7(2), 159-163.

Malczewski, J. (1999). GIS and Multicriteria Decision Analysis. New York: John Wiley \& Sons.

Mathews, A. J. \& Wikle, T. A. (2017). Assessing professional benefits of GIS certification. Cartography and Geographic Information Science, 44(5), 452-462.

Mulaku, G. C. (2013). Professionalism in GIS: International aspects of the certification debate. Journal of Geographic Information System, 5(4), 347.

Obermeyer, N. J. (1994). GIS: A new profession?. The Professional Geographer, 46(4), 498-503.

Obermeyer, N. J. (2007). GIS: The maturation of a profession. Cartography and Geographic Information Science, 34(2), $129-132$.

Oflaz, O.E., Bayraktar, H., Köksoy, E., Iravul, Y., Ölmez, A., Çabuk,A., Avdan, U., Çabuk, S.N., Bektöre, E., Orakoğlu, Ö., Çömert, R., Erdogan, S. \& Tiryakioğlu, í. (2013). Coğrafi bilgi sistemleri meslek standartları ve cbs kullanımının yaygınlaştırılması. $T M M O B$ Coğrafi Bilgi Sistemleri Kongresi'nde sunulmuştur. Ankara, Turkey.

PDRI, Inc. Aguirre International (2005) Technical Assistance Guide for Development and Using Competency Models-One Solution for a Demand-Driven Workforce System. Retrieved March 03, https://www.careeronestop.org/competencymodel/info_documents/tag.pdf.

Prager, S.D. \& Plewe, B. (2009). Assessment and evaluation of GIScience curriculum using the geographic information science and technology body of knowledge. Journal of Geography in Higher Education, 33(1), 46-S69.

Raper, J. \& Green, N. (1992). Teaching the principles of GIS: Lessons from the GISTutor project. International Journal of Geographical Information Systems, 6(4), 279-290. 
Rickles, P., Ellul, C. \& Haklay, M. (2017). A suggested framework and guidelines for learning GIS in interdisciplinary research. Geo: Geography and Environment, 4(2).

Rip, F.I., Wallentin. G. \& van Lammeren, R.J.A. (2014). Integrated analysis of the demand for and supply of geospatial education and training: Results of the GI-N2K Surveys. Scientific Report, Wageningen University, Laboratory of Geo-information Science and Remote Sensing, Netherlands. Retrieved August 14, 2017, http://www.gi-n2k.eu/surveys-results/.

Rogerson, P. \& Fotheringham, S. (2002). GIS and spatial analysis: introduction and overview. In S. Fotheringham, P. Rogerson (Eds.), Spatial Analysis and GIS, 3rd edn. (pp 1-10). London: Taylor and Francis Group.

Rogerson, R. J. (1992). Teaching generic GIS using commercial software. International Journal of Geographical Information Systems, 6(4), 321-331.

Sarı, F. (2013). Türkiye'de CBS öğretimi üzerine bir değerlendirme. TMMOB Coğrafi Bilgi Sistemleri Kongresi'nde sunulmuştur. Ankara, Turkey.

Schulze, U., Kanwischer, D. \& Reudenbach, C. (2013). Essential competences for GIS learning in higher education: A synthesis of international curricular documents in the GIS\&T domain. Journal of Geography in Higher Education, 37(2), 257-275.

Şeremet, M. \& Chalkley, B. (2016). Geography, GIS and employability in Turkey. Journal of Geography in Higher Education, 40(2), 238253.

Taş, H. í. (2006). Farklı CBS eğitim metodları ve programları. Marmara Coğrafya Dergisi, (13), 49-66.

Uça Avcı, D., Uça Güneş, P. \& Çabuk, A. (2015). Uzaktan eğitim ile uzaktan algılama ve coğrafi bilgi sistemleri eğitimlerinin verilmesine dair bir değerlendirme. Harita Teknolojileri Elektronik Dergisi, 7(3), 53-68.

UCGIS, (2006). Geographic Information Science and Technology Body of Knowledge. Washington: Association of American Geographers.

UCGIS, (2017). KE- 31 - Professional certification. Retrieved May 05, 2017, from http://gistbok.ucgis.org/bok-topics/professionalcertification.

URISA, (2012). Geospatial management competency model. Retrieved May 21, 2018, http://www.urisa.org/clientuploads/directory/GMI/Advocacy/GMCM\%20final.pdf.

USGIF, (2018). Professional certification. Retrieved May 21, 2018, http://usgif.org/certification.

Wallentin, G., Hofer, B. \& Traun, C. (2015). Assessment of workforce demands to shape GIS\&T Education. Transactions in GIS, 19, 439454.

Waters, N. M. (2013). The geographic information science body of knowledge 2.0: Toward a new federation of GIS knowledge. In O. Arnold, W. Spickermann, N. Spyratos, Y. Tanaka (Eds.), Webble technology, communications in computer and information science, Proceedings of the First Webble World Summit (pp. 129-142). Berlin: Springer.

Wikle, T. A. \& Fagin, T. D. (2015). Hard and soft skills in preparing GIS professionals: Comparing perceptions of employers and educators. Transactions in GIS, 19(5), 641-652.

Wikle, T. A. (1998). Continuing education and competency programmes in GIS. International Journal of Geographical Information Science, 12(5), 491-507.

Worboys, M.F. \& Duckham, M. (2004). GIS: A Computing Perspective (2nd ed.).New York: CRC Press.

Yiğit, i̇., Ataol, M. \& Dinç, A. (2011). Coğrafya bölümlerindeki CBS eğitimi ve CBS'nin gerekliliği. Marmara Coğrafya Dergisi, (24), 312331.

Young, M. (2005). National qualifications frameworks: Their feasibility for effective implementation in developing countries (No. 376646). Geneva: International Labor Organization. Retrieved November 22, 2018, from http://www.ilo.org/wcmsp5/groups/public/---ed_emp/---ifp_skills/documents/publication/wcms_103626.pdf. 